\title{
Uveal Melanoma Regression after Brachytherapy: Relationship with Chromosome 3 Monosomy Status
}

\author{
Sachin M. Salvi ${ }^{a}$ Hassan A. Aziz ${ }^{b}$ Suhail Dar ${ }^{c}$ Nakul Singh $^{c}$ \\ Brandy Hayden-Loreck ${ }^{b}$ Arun D. Singh ${ }^{b}$ \\ a Sheffield Ocular Oncology Service, Department of Ophthalmology, Royal Hallamshire Hospital, Sheffield, UK; \\ ${ }^{\mathrm{b}}$ Department of Ophthalmic Oncology, Cole Eye Institute, Cleveland Clinic, and ${ }^{\mathrm{C} C a s e}$ Western Reserve University \\ School of Medicine, Cleveland, Ohio, USA
}

\section{Key Words}

Uveal melanoma · Chromosome 3 monosomy · Metastasis ·

Prognostic factor

\begin{abstract}
Aim: The objective was to evaluate the relationship between the regression rate of ciliary body melanoma and choroidal melanoma after brachytherapy and chromosome 3 monosomy status. Methods: We conducted a prospective and consecutive case series of patients who underwent biopsy and brachytherapy for ciliary/choroidal melanoma. Tumor biopsy performed at the time of radiation plaque placement was analyzed with fluorescence in situ hybridization to determine the percentage of tumor cells with chromosome 3 monosomy. The regression rate was calculated as the percent change in tumor height at months 3, 6, and 12. The relationship between regression rate and tumor location, initial tumor height, and chromosome 3 monosomy (percentage) was assessed by univariate linear regression ( $R$ version 3.1.0). Results: Of the 75 patients included in the study, 8 had ciliary body melanoma, and 67 were choroidal melanomas. The mean tumor height at the time of diagnosis was $5.2 \mathrm{~mm}$ (range: 1.90-13.00). The percentage composition of chromosome 3 monosomy ranged from $0-20 \%(n=35)$ to $81-$ $100 \%(n=40)$. The regression of tumor height at months 3 ,
\end{abstract}

6, and 12 did not statistically correlate with tumor location (ciliary or choroidal), initial tumor height, or chromosome 3 monosomy (percentage). Conclusion: The regression rate of choroidal melanoma following brachytherapy did not correlate with chromosome 3 monosomy status.

ㄷ) 2016 S. Karger AG, Basel

\section{Introduction}

It has been over 50 years since Stallard [1] introduced plaque radiation therapy or brachytherapy as a treatment modality for ocular tumors (1962). The Collaborative Ocular Melanoma Study (COMS) further established radiation therapy as the primary treatment for medium-sized choroidal melanomas [2]. Various radioactive isotopes are used; with the gamma-radiating iodine 125 (I 125) [3] being more commonly used in American centers while the beta-radiating ruthenium $106(\mathrm{Ru} \mathrm{106})$ is more commonly used in Europe $[4,5]$. Whichever radioisotope is used, regression in the thickness of the tumor is considered as one of the major factors denoting successful treatment [6]. It is also accepted that larger tumors regress more than smaller tumors after brachytherapy [7].

Various characteristics of the tumor such as size, location, rate of growth, and extrascleral extension, amongst

\section{KARGER}

(c) 2016 S. Karger AG, Basel

E-Mail karger@karger.com

www.karger.com/oop
Arun D. Singh, MD

Department of Ophthalmic Oncology

Cole Eye Institute, Cleveland Clinic, 2022 E 105th Street

Cleveland, $\mathrm{OH} 44106$ (USA)

E-Mail singha@ccf.org 
others, have been identified to be of prognostic value in determining the risk of metastasis. The rate of regression of the uveal melanoma following brachytherapy as a prognostic factor for metastasis has been an issue of great interest and debate. Rapid regression of uveal melanoma following brachytherapy has been reported as an independent risk factor for metastasis [8-10].

Loss of chromosome 3 (i.e. monosomy 3 ) is one of the most significant determinants of tumor-related mortality [11-14]. The proportion of cells demonstrating chromosome 3 monosomy within a tumor varies widely from $0 \%$ (i.e. disomy 3) to $100 \%$ [15]. Increasing proportion of chromosome monosomy 3 cells within tumors has been correlated with worse prognosis [16].

Our study explores the relationship between the regression rate of ciliary body melanoma and choroidal melanoma following brachytherapy and percentage composition of chromosome 3 monosomy within the tumor. The relationship between regression rate and initial tumor height and tumor location was also investigated.

\section{Materials and Methods}

\section{Study Design and Enrollment}

This study was conducted at the Ophthalmic Oncology Service, Cole Eye Institute, Cleveland, Ohio, USA. In this prospective, consecutive, interventional case series, 150 patients with a clinical diagnosis of uveal melanoma were enrolled. Prognostication fineneedle aspiration biopsy was performed with the explicit purpose to enroll in a simultaneously conduced adjuvant therapy trial (ClinicalTrials.gov identifier: NCT01100528). Patients treated between May 2009 and July 2013 were included in this study. All patients were informed about the investigational nature of the study and provided written informed consent. Exclusion criteria were age $<18$ years, prior therapy of the primary tumor, and evidence of metastasis assessed at baseline. Therapy of the primary tumor included brachytherapy, enucleation, or tumor resection based upon the standard-of-care guidelines. Institutional Review Board (IRB) approval was obtained (local IRB No.: case 5608CC666).

\section{Data Collection}

Baseline information of patients including sex, age, and laterality of the tumor was documented. In addition to detailed history and visual acuity testing, ophthalmic examination was performed using slit-lamp examination, slit-lamp biomicroscopy with a 90 diopter lens, gonioscopy, and indirect ophthalmoscopy (where indicated). Ancillary studies including fundus photography, indocyanine angiography, and ultrasonography with B scan and standardized A scan were performed based upon clinical examination. The tumors' largest basal diameter and height were measured using ophthalmoscopy and B/A scan ultrasonography. The measurements were approximated to the nearest half millimeter. The location of the tumor was classified as ciliary body (including ciliochoroidal) or choroidal.

\section{Treatment}

Based on the clinical findings of the tumor, treatment modality was planned and discussed with the patient. Patient preference was taken into account. Broadly, treatment modality was radiation brachytherapy, enucleation (for tumors that were too large for brachytherapy), or local resection (for small anterior resectable tumors).

\section{Cytological/Fluorescence in situ Hybridization Analysis}

All patients underwent cytogenetic analysis of a tumor sample obtained by fine-needle aspiration biopsy using a 25-gauge needle at the time of plaque placement $[17,18]$. Anteriorly located tumors had an open flap transscleral biopsy, while posteriorly located tumors underwent a transvitreal biopsy under indirect ophthalmoscopy visualization. The specimen was immediately taken to the genetics laboratory in special transport media. Evaluation of the specimen was performed by an accredited cytopathologist using the fluorescence in situ hybridization (FISH) technique $[15,19]$. The minimum number of cells required for cytogenetic analysis was 200 cells; a smaller number of cells was considered to be an inadequate sample. The percentage of monosomy 3 within the tumor sample was reported as $0-20,21-40,41-60,61-80$, or $81-$ $100 \%$.

\section{Follow-Up}

Patients were evaluated at the first postoperative visit within 1-4 weeks followed by every 3 months in the first year and every 6 months thereafter. At every visit, in addition to clinical evaluation, each patient had ultrasonography to determine the height of the tumor. Follow-up data for months 3, 6, and 12 were used for the current study.

\section{Statistical Analysis}

From the collected database of 150 patients, only patients with choroidal/ciliary body melanoma who were treated with brachytherapy and who had a definitive diagnostic cytological result of melanoma were included in the current regression analysis study. Patients whose uveal melanomas were treated with enucleation or local resection $(n=49)$, who had iris or iridocilary tumors $(n=16)$, and wherein cytology was inadequate for FISH analysis $(\mathrm{n}=10)$ were excluded. Thus, the final cohort included in the statistical analysis was 75 patients.

Tumor regression was measured as a percentage of initial tumor height. Differences in tumor regression between baseline height, location, and the percentage of chromosome monosomy 3 were assessed by univariate linear regression at months 3,6 , and 12. All calculations were performed in $\mathrm{R}$ version 3.1.0.

\section{Results}

Of the 75 patients included in the study, 35 were male and 40 were female. The age range of the patients was between 27 and 89 years. Patients $<18$ years of age were excluded from the study. Nine patients were younger than 45 and 66 patients were older than 45 years of age. The mean age was 59.5 years. The right eye was involved in 41 patients, and the left eye in 34 patients. In 8 patients, the 
Fig. 1. Change in the tumor height of each tumor from baseline to months 3, 6, 9, and 12 of follow-up after brachytherapy $(\mathrm{n}=$ $75)$.

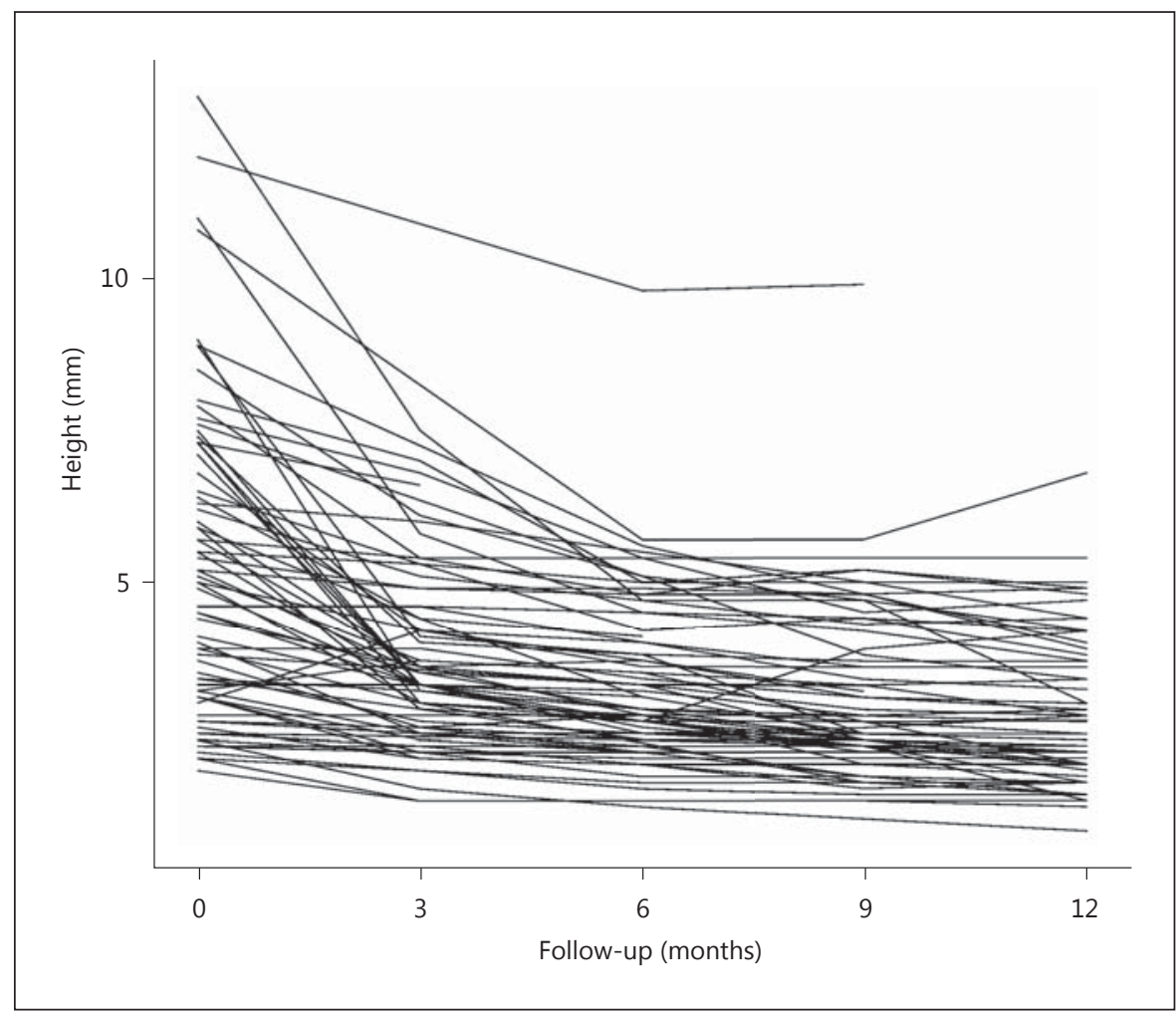

tumor was involving the ciliary body, while in 67 patients the tumor was purely choroidal in location. None of our patients had extraocular extension (table 1). All patients responded to brachytherapy, and there were no tumor recurrences in our study cohort.

The height of the tumors treated in our study was between $1.9 \mathrm{~mm}$ and a maximum of $13 \mathrm{~mm}$ (mean height: 5.15). Percentage monosomy identified was $0-20 \%$ in 35 patients, $21-40 \%$ in 5 patients, $41-60 \%$ in 7 patients, $61-$ $80 \%$ in 9 patients, and $81-100 \%$ in 10 patients. If the patients were to be divided in two large subgroups, 35 patients had less than $20 \%$ percentage monosomy, while 40 patients had more than $20 \%$ percentage monosomy.

Although the tumors were not classified according to COMS criteria, the larger tumors (height more than 10 $\mathrm{mm}$ ) showed greater regression than medium-sized tumors (height between 5.1 and $9.9 \mathrm{~mm}$ ), which in turn regressed more than the small-sized tumors (height less than $5 \mathrm{~mm}$ ). This statistically insignificant trend was noted at months 3, 6 as well as 12 of follow-up in terms of absolute height (fig. 1) and the percentage of the original height (fig. 2a). Each millimeter increase in baseline tumor height was associated with $3.4,4.4$, and $5.1 \%$ reduction in height following radiation therapy at months 3,6 , and 12 , respectively (table 2 ). With regards to location,
Table 1. Basic demographic data of the study cohort $(n=75)$

\begin{tabular}{ll}
\hline Sex & 35 \\
Male & \\
Female & \\
Age, years & $27-89$ \\
Range & 59.51 \\
Average & \\
Eye & 41 \\
$\quad$ Right & 34 \\
Left & \\
Location & 8 \\
Ciliary body & 67 \\
Choroid & \\
Height, mm & 5.15 \\
Mean & $1.90-13.00$ \\
Range & \\
Monosomy, $\%$ & 35 \\
$0-20$ & 5 \\
$21-40$ & 7 \\
$41-60$ & 9 \\
$61-80$ & 10 \\
$81-100$ & \\
Follow-up, months & 75 \\
3 & 75 \\
6 & 67 \\
12 &
\end{tabular}




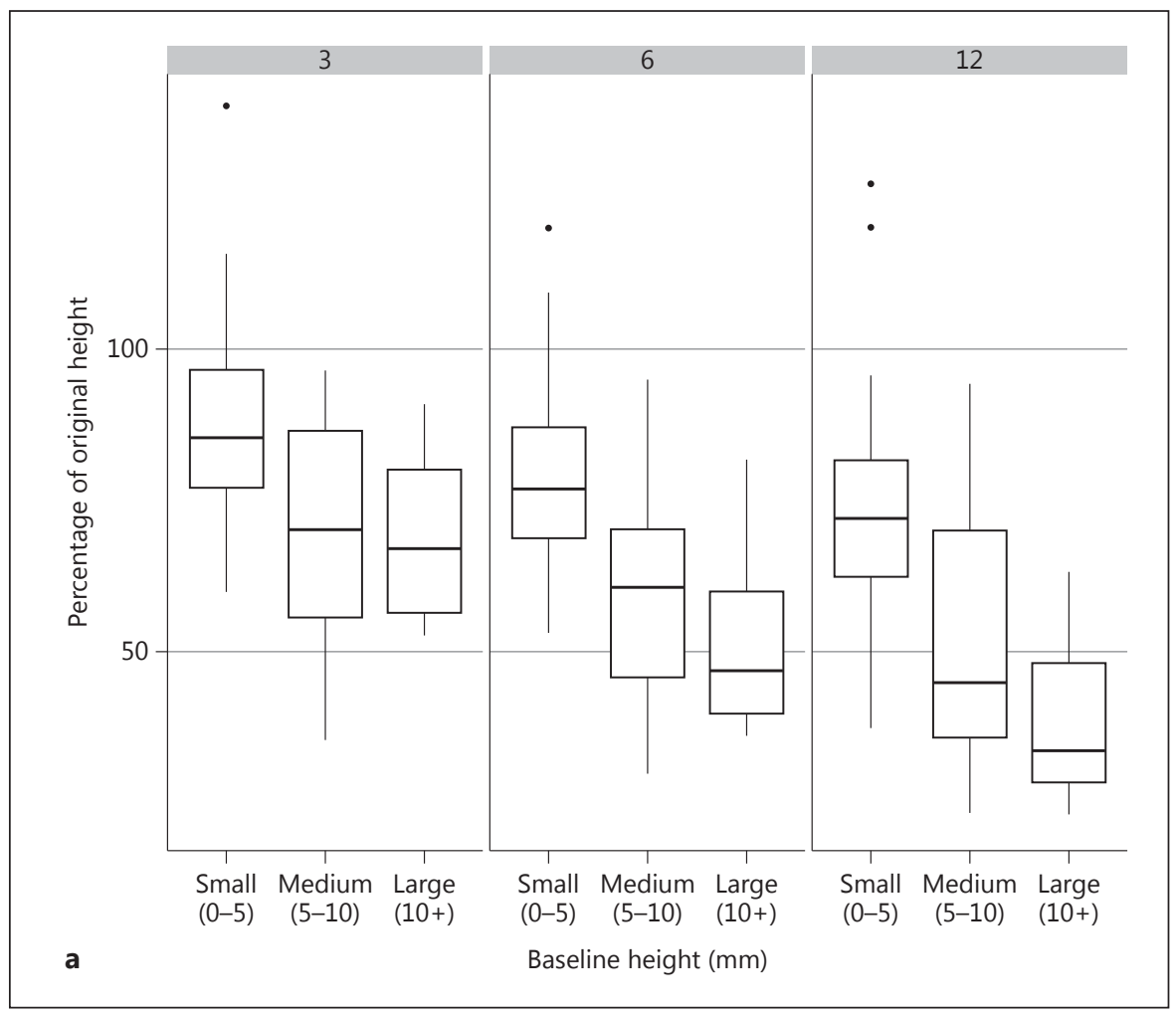

Fig. 2. Percent change in tumor height from baseline to months 3, 6, 9 and 12 following brachytherapy. a The tumors are grouped by initial tumor size: small tumors ( $<5 \mathrm{~mm}$ height), medium-sized tumors (5$10 \mathrm{~mm}$ height), and large tumors (>10 mm height). $\mathbf{b}$ The tumors are grouped by location: choroidal and ciliary body location.

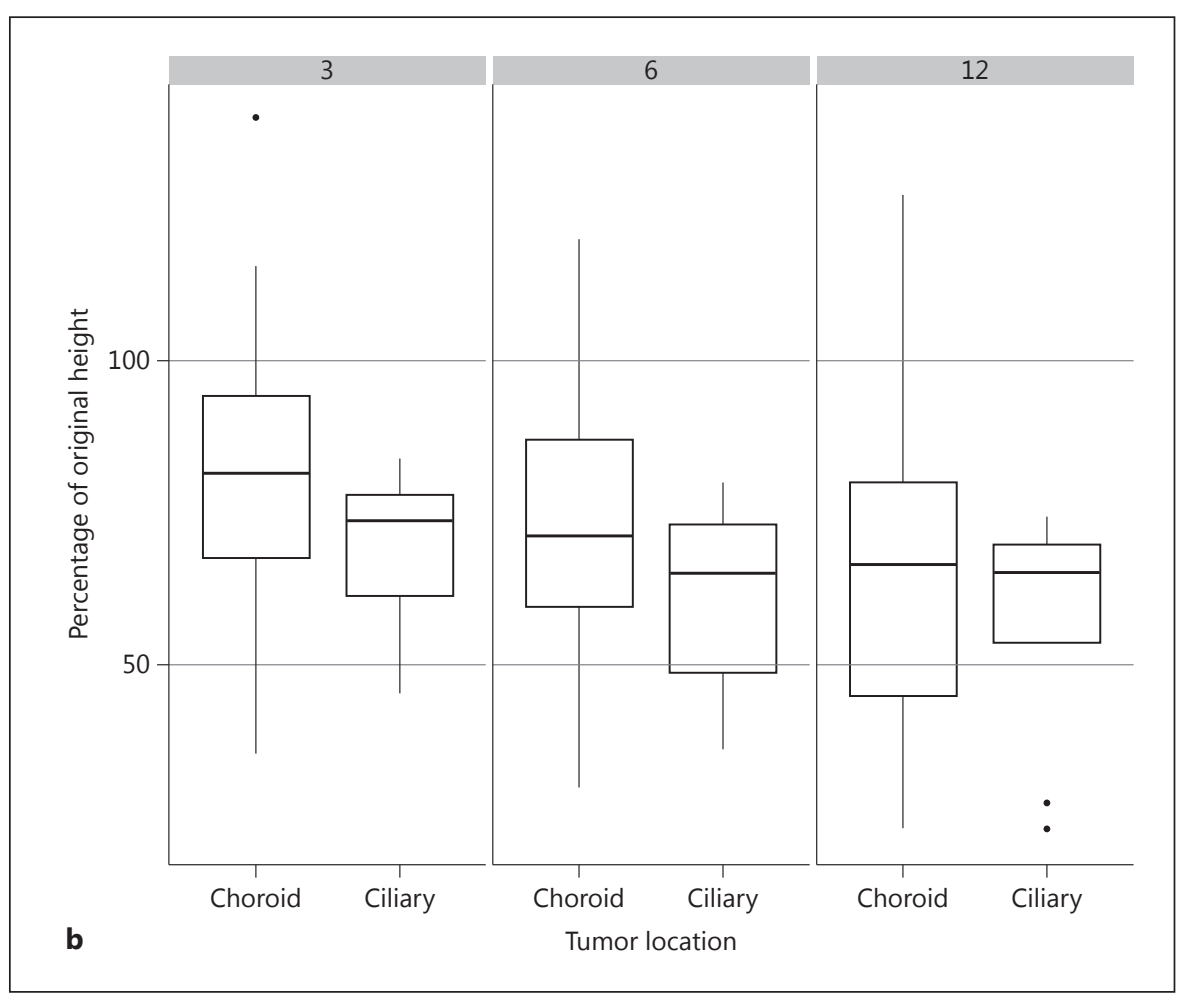

(For figure c see next page.) 
Fig. 2. Percent change in tumor height from baseline to months 3, 6, 9 and 12 following brachytherapy. c The tumors are grouped by percent monosomy $(<20$ and $\geq 20 \%$ ). The lower edge of the whisker represents the minimum value, the lower box edge the 1st quartile, the thick line the median, the upper box edge the 3rd quartile, and the upper edge of the whisker represents the maximum value. Isolated dots are outliers lying more than 1.5 times outside the interquartile range.

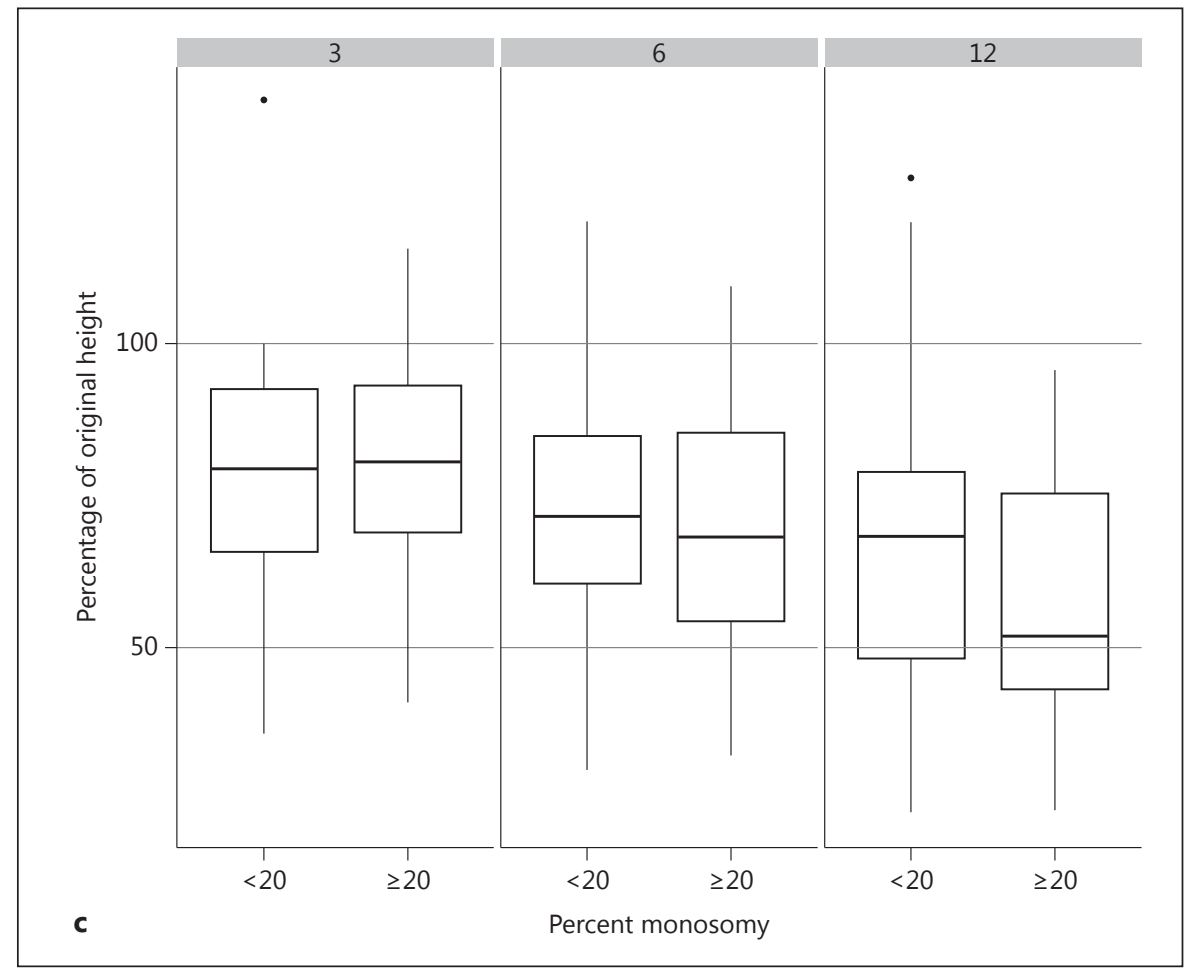

Table 2. Average tumor height as the percentage of baseline at 3, 6, and 12 months of follow-up

\begin{tabular}{|c|c|c|c|c|}
\hline Parameter & $\mathrm{n}$ & 3 months & 6 months & 12 months \\
\hline Male & 35 & $77(70$ to 83$)$ & $69(63$ to 76$)$ & $63(54$ to 71$)$ \\
\hline Female & 40 & $81(75$ to 87$)$ & $72(65$ to 78$)$ & $63(55$ to 70$)$ \\
\hline \multicolumn{5}{|l|}{ Age, years } \\
\hline \multicolumn{5}{|l|}{ Eye } \\
\hline Right & 40 & $79(73$ to 85$)$ & $72(66$ to 78$)$ & $62(55$ to 70$)$ \\
\hline Left & 35 & $80(74$ to 86$)$ & $70(63$ to 77$)$ & $64(56$ to 72$)$ \\
\hline \multicolumn{5}{|l|}{ Location } \\
\hline Ciliary body & 8 & $69(56$ to 82$)$ & $61(47$ to 74$)$ & $57(42$ to 73$)$ \\
\hline $\mathrm{p}$ value & & $<0.001$ & $<0.001$ & $<0.001$ \\
\hline \multicolumn{5}{|c|}{ Chromosome 3 monosomy, $\%^{a}$} \\
\hline 0 to 20 & 34 & $76(69$ to 83$)$ & $68(61$ to 75$)$ & 61 (53 to 69) \\
\hline 21 to 40 & 5 & $76(59$ to 93$)$ & $67(49$ to 84$)$ & $60(41$ to 79$)$ \\
\hline 41 to 60 & 7 & $76(61$ to 90$)$ & $69(54$ to 84$)$ & $58(42$ to 74$)$ \\
\hline 61 to 80 & 9 & $86(73$ to 99$)$ & $79(65$ to 93$)$ & $68(51$ to 86$)$ \\
\hline 81 to 100 & 10 & $78(67$ to 90$)$ & 65 (53 to 77 ) & 53 (39 to 67$)$ \\
\hline $\mathrm{p}$ value & & 0.75 & 0.65 & 0.74 \\
\hline
\end{tabular}

Statistical analysis of determinants. ${ }^{a}$ FISH $=$ Unknown status in 10 cases due to technical failure.

Uveal Melanoma Regression after Brachytherapy
Ocul Oncol Pathol 2017;3:87-94 DOI: $10.1159 / 000451001$ 
Fig. 3. Scatter graph showing the percent change of the initial height when plotted against the percentage composition of chromosome 3 monosomy (x axis). There is no identifiable co-relation between the two parameters at months 3, 6 or 12 following brachytherapy.

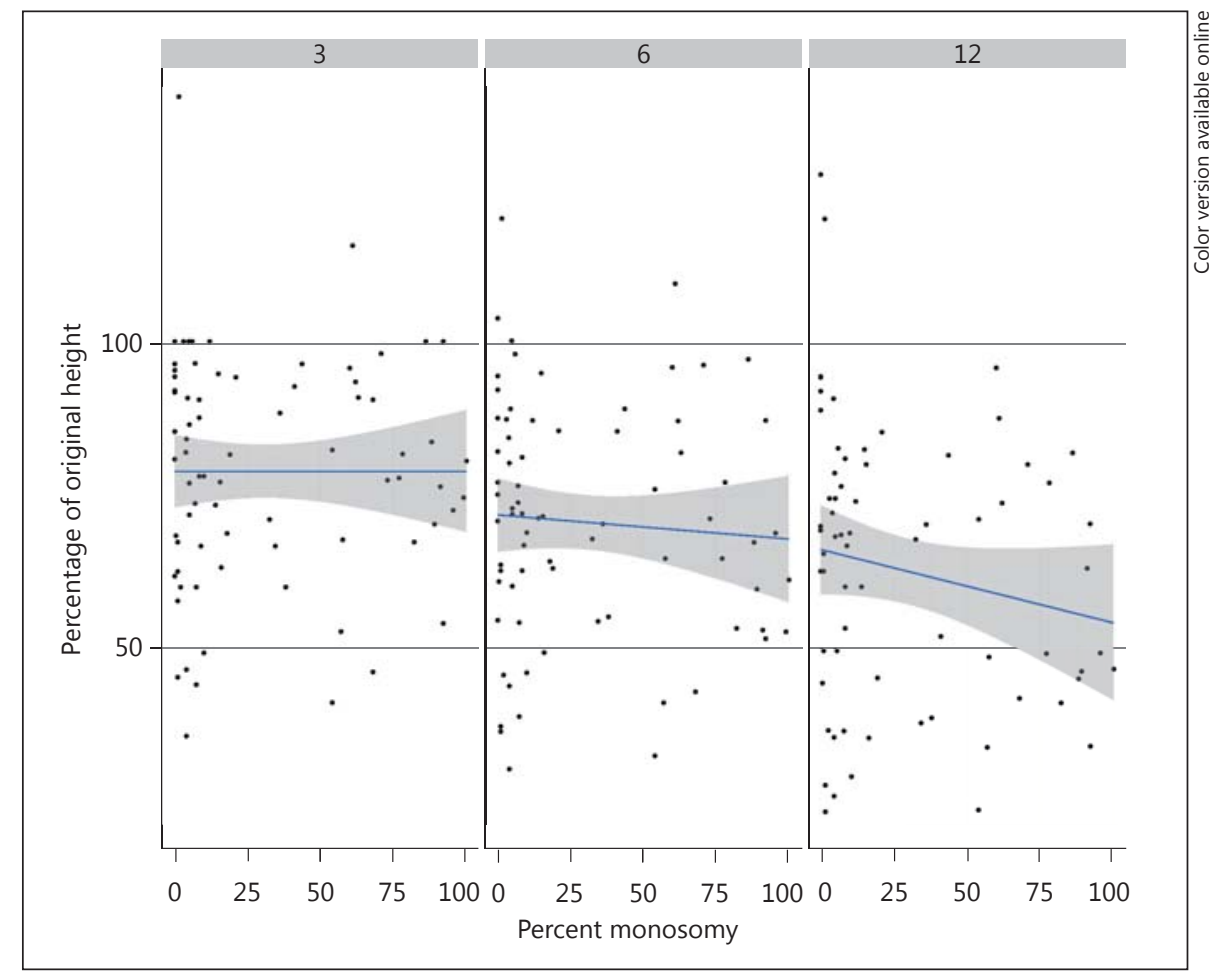

ciliary body melanoma had a slightly higher percent reduction in tumor height when compared to choroidal melanoma (statistically insignificant difference) (fig. 2b).

No statistically significant difference was identified between the tumors with a low or high percentage of chromosome monosomy 3 cells (percent chromosome monosomy of $<20 \%$ vs. $\geq 20 \%$ ) (fig. 2 c). Moreover, analysis based upon composition (any percentage chromosome 3 monosomy cells) also did not reveal any difference (fig. 3 ).

\section{Discussion}

It has been previously reported that a higher rate of regression following radiation therapy in uveal melanoma correlated with an increased risk of metastasis [8-10]. With the advent of genetic testing, monosomy 3 and gene expression profiling are now considered as more reliable prognostic indicator for metastatic potential in uveal melanoma [11-14]. In the present study, the regression rate in the height of uveal melanoma at months 3,6 , and 12 following brachytherapy did not correlate with chromosome 3 monosomy status of the tumor sample.

Prior correlative studies that have assessed the rate of regression of a tumor and its chromosome 3 status have reported conflicting results [20-22]. Rapid regression was either noticed in a study limited to ciliochoroidal melanoma [21] or in a study that included tumors treated with transpupillary thermotherapy in addition to brachytherapy [20]. Chiam et al. [22] reported absence of correlation between the rate of regression following radiation therapy and chromosome 3 status in a larger study (149 cases), supporting our observation. Similarly, other studies assessing prognostication with gene expression profiling have reported either lack of correlation with the following radiation regression rate $[23,24]$ or reverse correlation of rapid regression in tumors with better prognosis (table 3) [25].

To our knowledge, this is the first study to use FISH analysis to explore the regression rates with the percentage of tumor cells with chromosome 3 monosomy as a continuous variable. Whether the patients were subdivided into six discrete groups $(0-20,21-40,41-60,61-80$, and $81-100 \%)$ or in two larger groups $(<20$ or $\geq 20 \%)$ depending on the percentage of chromosome 3 monosomy status of tumor cells, the statistical difference in regression rates amongst any of the groups was not observed. Moreover, the location (ciliary vs. choroidal) or initial height of the tumor also had no statistical correlation with the regression rates following radiation therapy. 
Table 3. Correlation between the regression of uveal melanomas and chromosome 3 status

\begin{tabular}{|c|c|c|c|c|c|c|}
\hline $\begin{array}{l}\text { First author } \\
\text { [ref.] }\end{array}$ & Year & $\mathrm{n}$ & Therapy & $\begin{array}{l}\text { Prognostication } \\
\text { technique }\end{array}$ & Outcome & Result \\
\hline Shields [20] & 2008 & 270 & $\begin{array}{l}\text { Plaque radiation } \\
(\mathrm{I} 125)+\mathrm{TTT}\end{array}$ & MSA & $\begin{array}{l}\text { The overall regression rate (59 } \\
\text { and } 71 \% \text { ) at } 12 \text { and } 15 \text { months, } \\
\text { respectively }\end{array}$ & $\begin{array}{l}\text { Regression rate greater with } \\
\text { chromosome } 3 \text { loss }\end{array}$ \\
\hline Marathe [21] & 2011 & 40 & $\begin{array}{l}\text { Plaque radiation } \\
\text { (I 125) }\end{array}$ & FISH & $\begin{array}{l}\text { Decrease in thickness at } 1.75 \\
\text { years }\end{array}$ & $\begin{array}{l}\text { Regression greater with } \\
\text { chromosome } 3 \text { loss (only } \\
\text { ciliochoroidal melanoma) }\end{array}$ \\
\hline Chappell [23] & 2012 & 197 & Proton radiation & GEP & $\begin{array}{l}\text { Mean change in thickness or } \\
\text { overall rate of thickness change } \\
\text { at } 24 \text { months }\end{array}$ & $\begin{array}{l}\text { Regression rate not related to } \\
\text { GEP class }\end{array}$ \\
\hline Correa [24] & 2014 & 50 & $\begin{array}{l}\text { Plaque radiation } \\
\text { (I 125) }\end{array}$ & GEP & $\begin{array}{l}\text { Mean tumor thickness and } \\
\text { percent regression ( } 29 \text { and } 31) \\
\text { at } 3 \text { and } 6 \text { months }\end{array}$ & $\begin{array}{l}\text { Regression rate not related to } \\
\text { GEP class }\end{array}$ \\
\hline Rao [25] & 2015 & 138 & $\begin{array}{l}\text { Plaque radiation } \\
\text { (I 125) }\end{array}$ & GEP & $\begin{array}{l}\text { Mean reduction in tumor } \\
\text { thickness at } 3 \text { months }\end{array}$ & $\begin{array}{l}\text { Class } 1 \text { uveal melanoma } \\
\text { tumors exhibit more rapid } \\
\text { early tumor regression than } \\
\text { class } 2 \text { tumors }\end{array}$ \\
\hline Present study & 2015 & 75 & $\begin{array}{l}\text { Plaque radiation } \\
\text { (I 125) }\end{array}$ & FISH & $\begin{array}{l}\text { Percent reduction in thickness } \\
\text { at } 12 \text { months }\end{array}$ & $\begin{array}{l}\text { Regression rate not related to } \\
\text { chromosome } 3 \text { loss }\end{array}$ \\
\hline
\end{tabular}

Review of published studies. MSA = Microsatellite assay; GEP = gene expression profiling; MLPA = multiplex ligation-dependent probe amplification; TTT $=$ transpupillary thermotherapy.

Our results are in agreement with some of the previously reported studies [19,21,23].

A prospective study design, cytopathologic confirmation of uveal melanoma, standardized posttreatment follow-up, and use of percentage chromosome 3 monosomy composition as a continuous variable within the tumor are some of the strengths of our study. As our study was strongly weighted to choroidal melanoma (89\%), the results cannot be extended to ciliary body melanoma.

In conclusion, our study shows that regression rates following radiation therapy do not correlate with chromosome 3 monosomy status of the choroidal melanoma. Hence, the regression rate of choroidal melanoma following brachytherapy cannot be used as an independent prognostic factor.

\section{Acknowledgments}

Our study was supported by FALK Trust, Chicago, and Ratner Foundation, New York, and in part by an unrestricted grant from the Research to Prevent Blindness by the Cole Eye Institute.

Uveal Melanoma Regression after

Brachytherapy

\section{Statement of Ethics}

The study complied with the guidelines for human studies and animal welfare regulations. The subject gave informed consent, and the study protocol was approved by the institute's committee on human research.

\section{Disclosure Statement}

The authors have no conflicts of interest to declare.

\section{References}

1 Stallard HB: Radiotherapy for malignant melanoma of the choroid. Br J Ophthalmol 1966; 50:147-155.

2 Diener-West M, Earle JD, Fine SL, et al: The COMS randomized trial of iodine 125 brachytherapy for choroidal melanoma, III: initial mortality findings. COMS Report No. 18. Arch Ophthalmol 2001;119:969-982.

3 Earle J, Kline RW, Robertson DM: Selection of iodine 125 for the Collaborative Ocular Melanoma Study. Arch Ophthalmol 1987; 105:763-764. 
4 Lommatzsch PK: Beta-irradiation of choroidal melanoma with $106 \mathrm{Ru} / 106 \mathrm{Rh}$ applicators. 16 years' experience. Arch Ophthalmol 1983; 101:713-717.

5 Seregard S: Long-term survival after ruthenium plaque radiotherapy for uveal melanoma. A meta-analysis of studies including 1,066 patients. Acta Ophthalmol Scand 1999;77:414417.

6 Georgopoulos M, Zehetmayer M, Ruhswurm I, et al: Tumor regression of uveal melanoma after ruthenium-106 brachytherapy or stereotactic radiotherapy with gamma knife or linear accelerator. Ophthalmologica 2003;217: 315-319.

7 Kaiserman I, Anteby I, Chowers I, Blumenthal EZ, Kliers I, Pe'er J: Changes in ultrasound findings in posterior uveal melanoma after ruthenium 106 brachytherapy. Ophthalmology 2002;109:1137-1141.

8 Kaiserman I, Anteby I, Chowers I, Blumenthal EZ, Kliers I, Pe'er J: Post-brachytherapy initial tumor regression rate correlates with metastatic spread in posterior uveal melanoma. Br J Ophthalmol 2004;88:892-895.

9 Glynn RJ, Seddon JM, Gragoudas ES, Egan KM, Hart LJ: Evaluation of tumor regression and other prognostic factors for early and late metastasis after proton irradiation of uveal melanoma. Ophthalmology 1989;96:1566-1573.

10 Augsburger JJ, Gamel JW, Shields JA, Markoe AM, Brady LW: Post-irradiation regression of choroidal melanomas as a risk factor for death from metastatic disease. Ophthalmology 1987;94:1173-1177.
11 Scholes AG, Damato BE, Nunn J, Hiscott P, Grierson I, Field JK: Monosomy 3 in uveal melanoma: correlation with clinical and histologic predictors of survival. Invest Ophthalmol Vis Sci 2003;44:1008-1011.

12 Prescher G, Bornfeld N, Hirche H, Horsthemke B, Jockel KH, Becher R: Prognostic implications of monosomy 3 in uveal melanoma. Lancet 1996;347:1222-1225.

13 Ehlers JP, Worley L, Onken MD, Harbour JW: Integrative genomic analysis of aneuploidy in uveal melanoma. Clin Cancer Res 2008; 14:115-122.

14 Aalto Y, Eriksson L, Seregard S, Larsson O, Knuutila S: Concomitant loss of chromosome 3 and whole arm losses and gains of chromosome 1,6 , or 8 in metastasizing primary uveal melanoma. Invest Ophthalmol Vis Sci 2001; 42:313-317.

15 Aronow M, Sun Y, Saunthararajah Y, et al: Monosomy 3 by FISH in uveal melanoma: variability in techniques and results. Surv Ophthalmol 2012;57:463-473.

16 van den Bosch T, van Beek JG, Vaarwater J, et al: Higher percentage of FISH-determined monosomy 3 and $8 \mathrm{q}$ amplification in uveal melanoma cells relate to poor patient prognosis. Invest Ophthalmol Vis Sci 2012;53:26682674.

17 Singh AD, Pelayes DE, Brainard JA, Biscotti CV: History, indications, techniques and limitations. Mono Cytol 2012;21:1-9.

18 Turell ME, Tubbs RR, Biscotti CV, Singh AD: Uveal melanoma: prognostication. Monogr Clin Cytol 2012;21:55-60.
19 Singh AD, Aronow ME, Sun Y, et al: Chromosome 3 status in uveal melanoma: a comparison of fluorescence in situ hybridization and single-nucleotide polymorphism array. Invest Ophthalmol Vis Sci 2012;53:3331-3339.

20 Shields CL, Bianciotto C, Rudich D, Materin MA, Ganguly A, Shields JA: Regression of uveal melanoma after plaque radiotherapy and thermotherapy based on chromosome 3 status. Retina 2008;28:1289-1295.

21 Marathe OS, Wu J, Lee SP, et al: Ocular response of choroidal melanoma with monosomy 3 versus disomy 3 after iodine-125 brachytherapy. Int J Radiat Oncol Biol Phys 2011;81:1046-1048.

22 Chiam PJ, Coupland SE, Kalirai H, Groenewald C, Heimann H, Damato BE: Does choroidal melanoma regression correlate with chromosome 3 loss after ruthenium brachytherapy? Br J Ophthalmol 2014;98: 967-971.

23 Chappell MC, Char DH, Cole TB, et al: Uveal melanoma: molecular pattern, clinical features, and radiation response. Am J Ophthalmol 2012;154:227-232.

24 Correa ZM, Augsburger JJ: Relationship between rate of posterior uveal melanoma flattening following plaque radiotherapy and gene expression profile class of tumor cells. Invest Ophthalmol Vis Sci 2014;55:556-559.

25 Rao RC, Khan M, Badiyan SN, Harbour JW: Gene expression profiling and regression rate of irradiated uveal melanomas. Ophthal Surg Laser 2015;46:333-337. 